\title{
Tritium along the French coast of the English Channel
}

\author{
M. Masson ${ }^{1}$, F. Siclet ${ }^{2}$, M. Fournier ${ }^{3}$, A. Maigret ${ }^{2}$, G. Gontier ${ }^{4}$ \\ and P. Bailly du Bois ${ }^{1}$ \\ ${ }^{1}$ Laboratoire de Radioécologie de Cherbourg-Octeville, IRSN/DEI/SECRE, \\ 50130 Cherbourg-Octeville, France \\ ${ }^{2} E D F R \& D$ Département LNHE, 6 quai Watier, 78401 Chatou, France \\ ${ }^{3}$ LMRE, IRSN/DEI/STEME, Bât. 501, Bois des Rames, 91400 Orsay, France \\ ${ }^{4}$ LERCM, IRSN/DEI/SESURE, 13115 St. Paul-Lez-Durance, France
}

\begin{abstract}
Within the scope of a joint IRSN/EDF research program, it is possible to present a first status of free water tritium and organically bound tritium levels in the French coastal marine environment, from Concarneau to Gravelines. Seasonal sampling was conducted over two years, 2001 and 2002. The matrices selected for this specific survey include water, seaweed, molluscs, crustaceans and fish. The background concentration, estimated from the results obtained at two sites, Concarneau and Roscoff, remote from industrial sources, is close to the detection limit of 1,2 Bq. $\mathrm{l}^{-1}$. Along the Channel coast and the entrance of the North Sea, tritium is released in seawater by four nuclear power plants (14 reactors) and mainly by the reprocessing plant of La Hague. The concentrations measured are in good agreement with activities calculated with the hydrodynamic model of dispersion TRANSMER. The results confirm a dilution factor of two between the north Cotentin area and the Straits of Dover for soluble radionuclides. The concentrations are in the range of 2 to $20 \mathrm{~Bq} . \mathrm{l}^{-1}$ for free and organically bound tritium in biota. Although isotopic fractionation is theoretically expected to be slight, the available results indicate a ratio between tritium bound to organic matter and tritium in free water greater than one.
\end{abstract}

\section{INTRODUCTION}

Tritium present in the environment may originate from various sources: it is produced naturally by cosmic radiation, and artificially during nuclear weapon tests in the atmosphere and in nuclear plant reactors. It is also used as a marker for biological, medical and pharmacological research needs and as a luminescent substance in luminous dials. It may therefore be found in nuclear industry releases (power plants and reprocessing plants) but also in releases from research centers, hospitals and facilities manufacturing molecules marked with tritium. Along the French coast of the English Channel, most of the releases come from the COGEMA La Hague nuclear reprocessing plant $\left(\left(\cong 10^{4} \mathrm{TBq}_{\text {.year }}^{-1}\right)\right.$ and from the nuclear power plants of Flamanville, Paluel, Penly and Gravelines on the French side

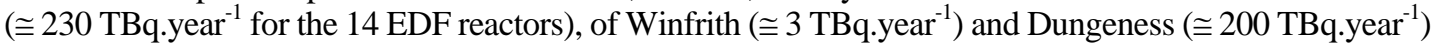
on the English side.

As there are very few published data concerning tritium concentrations in the English Channel [1], the purpose of this study is to provide a reference status of the marine environment contamination induced by the operation of these facilities. A joint sampling and analysis program was conducted by IRSN and EDF in 2001 and 2002, in the various ecosystem compartments. This allowed characterizing concentrations of free tritium (HTO) and of organically bound tritium (OBT) in green, red and brown algae, molluscs, crustaceans and fish and compare them to seawater concentrations. These first results are compared to the results simulated by the hydrodynamic model of dispersion Transmer [2], and to unpublished data concerning the years 1998 to 2000 in the north Cotentin. 


\section{SAMPLING AND ANALYSIS METHODS}

Brown algae (Fucus serratus and vesiculosus) and seawater were sampled in 2001 and 2002 in about ten stations along the French coast from Concarneau, on the south coast of Brittany to Gravelines, at the entrance of the North sea, close to the Belgium border (Figure 1). In the region of the Gravelines nuclear plant, this brown algae sampling was completed by samples of green and red algae, mussels (soft parts) and fish (muscles). On the Atlantic coast, the Concarneau station was selected, for the same species, as a reference station, away from any nuclear industry.

Bound tritium must be separated from free tritium to be measured. Then, it must be transformed in order to be analyzed [3]. The fresh sample is freeze-dried. The collected water is analyzed as free tritium and the dryness fraction is transformed by pyrolysis then oxidized in a pipe still. The water vapor condensed in a cold trap indicates the quantity of organically bound tritium. The knowledge of the sample hydrogen rate allows adapting the quantity necessary for the analysis and calculating the efficiency of the transformation into water. Seawater samples are purified by distillation. The water is mixed with the scintillant liquid "UltimaGold Low Level Tritium" and the counting is ensured by low background scintillation counters (Packard 2770 TR/SL or Quantulus 1220). The counting rate of samples is measured almost concurrently with a blank and a reference solution. Every measurement lasts 1,000 minutes. The efficiency and detection limit are estimated for every counting group. The detection limit is about $1,2 \mathrm{~Bq} \cdot \mathrm{l}^{-1}$.

The Atlantic water background was determined using samples carried out by P. Morin (CNRS-Roscoff) during the Ovide 2002 campaign. Concentrations were measured by helium-3 decrease at the University of Breme (Germany).

\section{RESULTS}

In the north-west Cotentin, owing to the closeness of the release from the COGEMA La Hague reprocessing plant, the average concentrations in seawater on the coast are very fluctuating depending on the chronology of releases and the movements of tidal currents. The concentrations measured every month in seawater at Goury (station 7) in 2001-2002 vary from 3 to 23 Bq..$^{-1}$ (Figure 1).

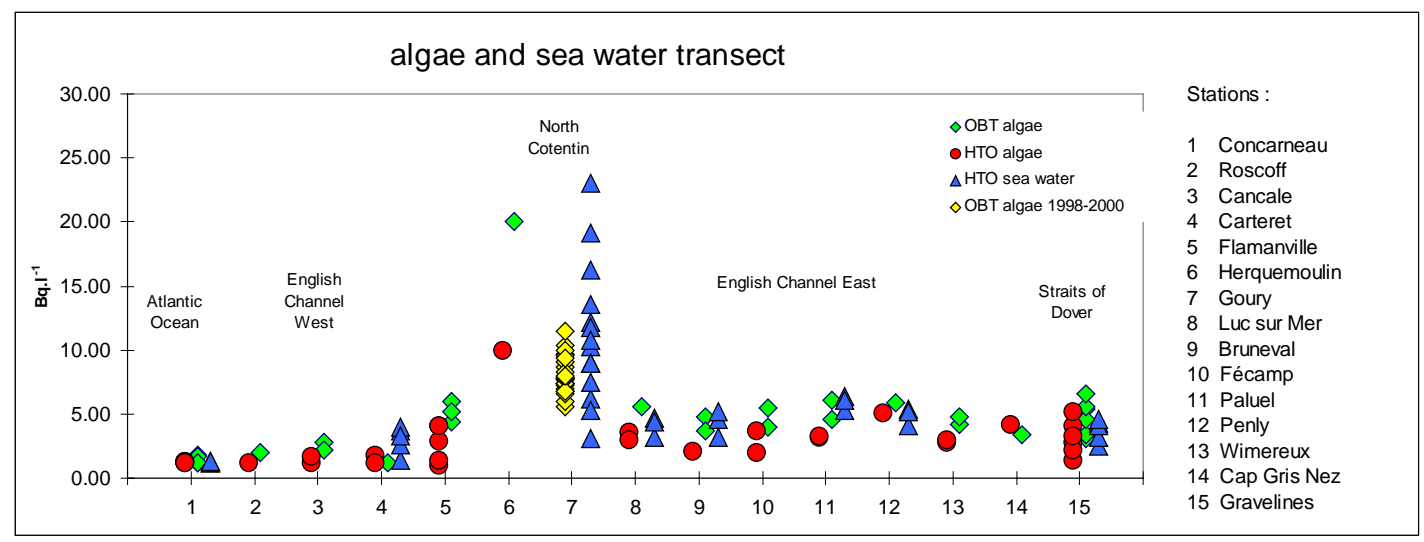

Figure 1. HTO and OBT concentrations measured in seawater and algae between Concarneau and Gravelines from 1998 to 2002.

In the east Cotentin, HTO concentrations measured in seawater along the French coast of the English Channel are quite homogeneous and comprised between 3,7 and 5,9 Bq. $\mathrm{I}^{-1}$. In the west Cotentin, along Brittany coast, concentrations are lower than the detection limit $\left(1.2 \mathrm{~Bq} \cdot \mathrm{l}^{-1}\right)$. Measurements by mass spectrometry allowed determining the Atlantic water activity in the south of Ireland, which is about $0,15 \mathrm{~Bq} \cdot \mathrm{I}^{-1}$. 
Free tritium concentrations measured in seawater are compared to the average concentrations calculated for the years 2001-2002 using the hydrodynamic model of dispersion TRANSMER [1] (figure 2). The model takes into account the individual tritium releases from the COGEMA La Hague plant and the annual average releases from other French and English facilities. The average concentration calculated along the coast in the eastern English Channel and in the Straits of Dover is about $4 \mathrm{~Bq} . \mathrm{l}^{-1}$, with a dilution factor ranging from 2 to 3 between the north Cotentin and the Straits of Dover, which confirms the previous estimates [4][5]. Generally, there is a good consistency between the concentrations measured along the coast of the English Channel and the concentrations calculated by Transmer (Figure 3). The calculation-measurements discrepancy is lower at Luc sur Mer (station 8) or Bruneval (station 9), stations located far from nuclear plant releases, than close to the Paluel (station 11) and Penly (station 12) plants.

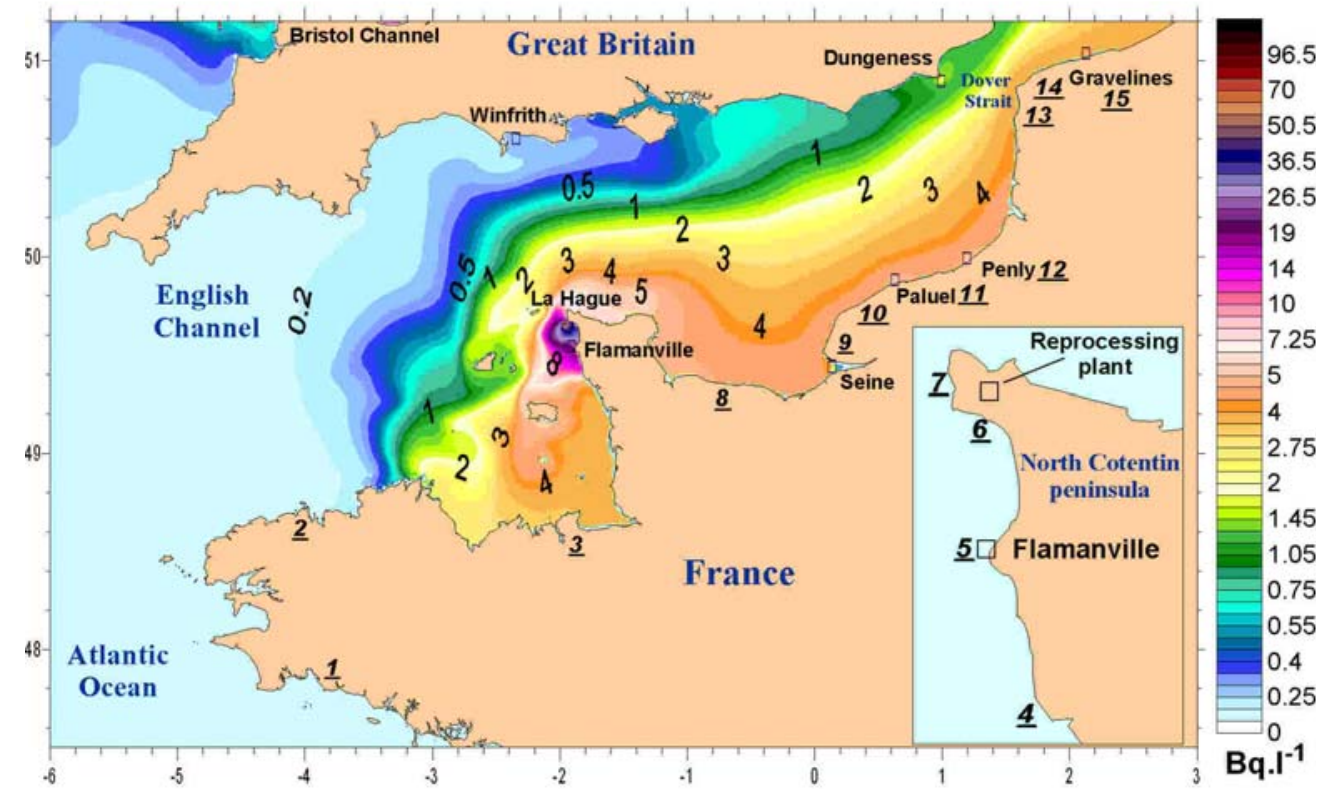

Figure 2. Chart of the average tritium concentrations in seawater in the English Channel, in 2001-2002, calculated using the TRANSMER model considering the releases from all the nuclear plants on the French and English coast. ( : nuclear facilities; 1 to 15 : sampling stations, list in figure 4).

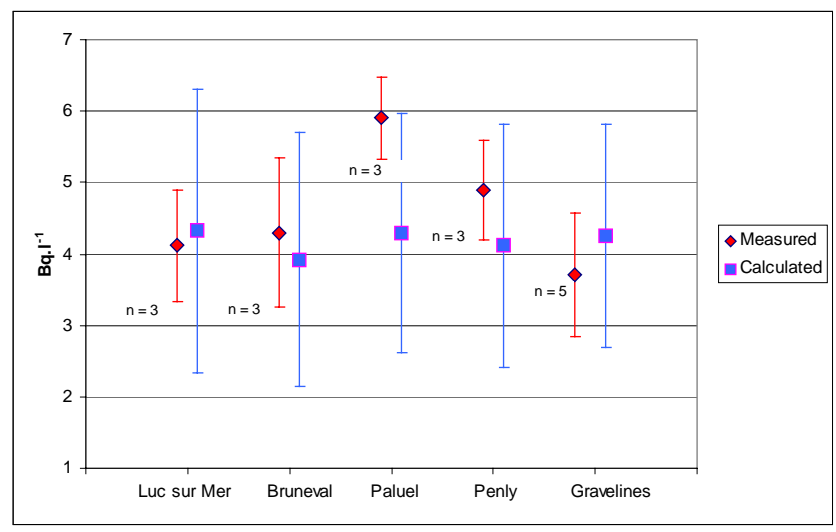

Figure 3. Tritium concentrations measured and tritium concentrations calculated with a daily step time over 2001-2002 by TRANSMER in 5 stations of the English Channel (Bq. $l^{-1} \pm 1 \sigma$ ). 
The simulations carried out using TRANSMER without taking into account releases from La Hague plant allow a better viewing of the concentrations added in the English Channel by the releases from nuclear power plants and by the Seine river supply. They are in the range of 1 to $2 \mathrm{~Bq}^{-\mathrm{l}^{-1}}$ in the environment close to the plants (figure 4).

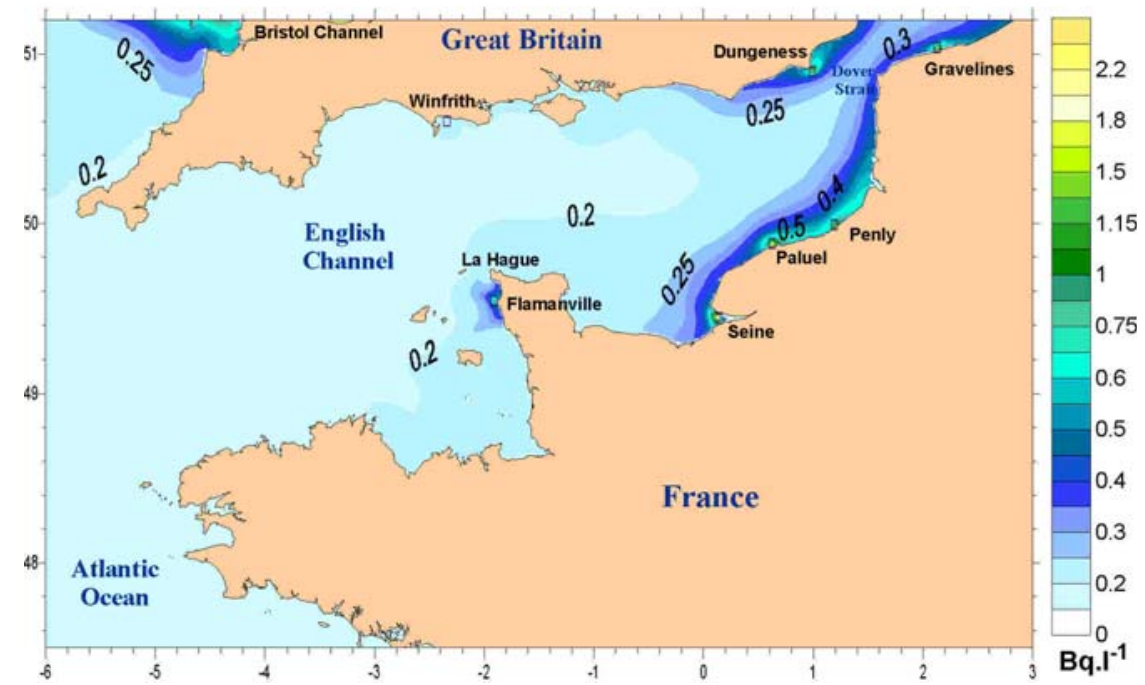

Figure 4. Chart of the average tritium concentrations in seawater in the English Channel, in 2001-2002, calculated using the TRANSMER model considering the releases from all nuclear plants on the French and English coast without the releases from the COGEMA La Hague plant.

The spatial trends of tritium concentrations measured in algae are consistent with the seawater evolution (Figure 1). The influence of La Hague plant is obviously predominant in the north Cotentin with concentrations reaching about $20 \mathrm{~Bq} \cdot \mathrm{l}^{-1}$. To the east, in the eastern English Channel and in the strait of Dover, concentrations vary from 1,2 to $6,5 \mathrm{~Bq} . \mathrm{l}^{-1}$. The maximum concentrations are measured in the Gravelines plant environment, where seawater, algae and mussels were sampled at the end of the release channel, in the plume of the plant releases.

At Gravelines, the comparison of the measurement results to the results of the TRANSMER model simulations show that samples have generally greater HTO concentrations in the theoretical marking because of the COGEMA La Hague reprocessing plant (figure 5). However, it should be noted that in March 2002, the TRANSMER model seems to overestimate, in line with Gravelines, the supplies bound to the releases from COGEMA La Hague.

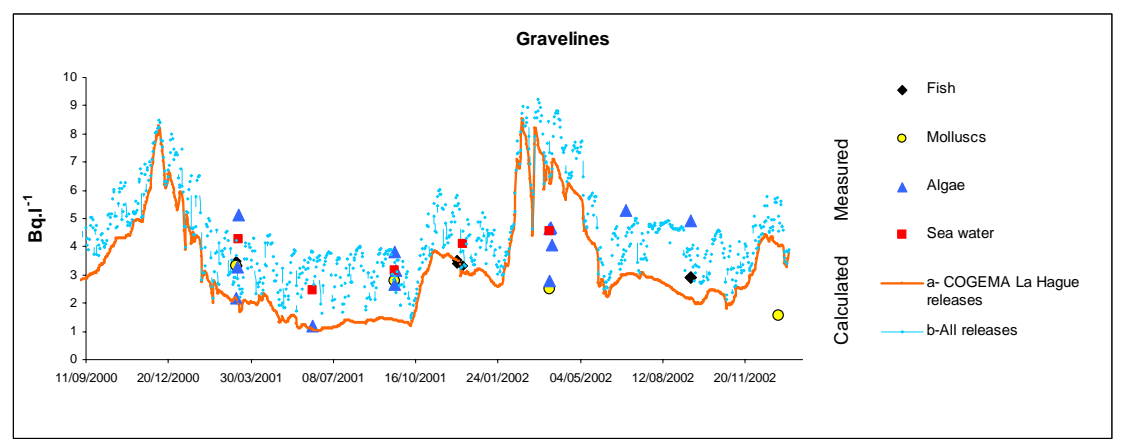

Figure 5. HTO concentrations measured in various matrices at Gravelines in 2001-2002 and HTO concentrations calculated with the TRANSMER model: (a) for releases from La Hague plant, (b) for releases from all nuclear facilities in the English Channel. 
HTO concentrations measured in all algae sampled within the scope of this study are lower than the HTO concentrations measured in seawater (figure 6 a). A better correlation is observed between OBT concentrations of algae and HTO concentrations of seawater (figure $6 \mathrm{~b}$ ). In algae, the ratio between OBT and HTO is $1,68 \pm 0,5(n=23)$.

At Gravelines, the major discrepancies between OBT and HTO are observed in mussels (table 1). At Concarneau, the OBT concentrations are greater than the detection limits unlike the HTO concentrations (table 2). It should also be noted that crustaceans and molluscs have the greatest OBT concentrations among the studied matrices.

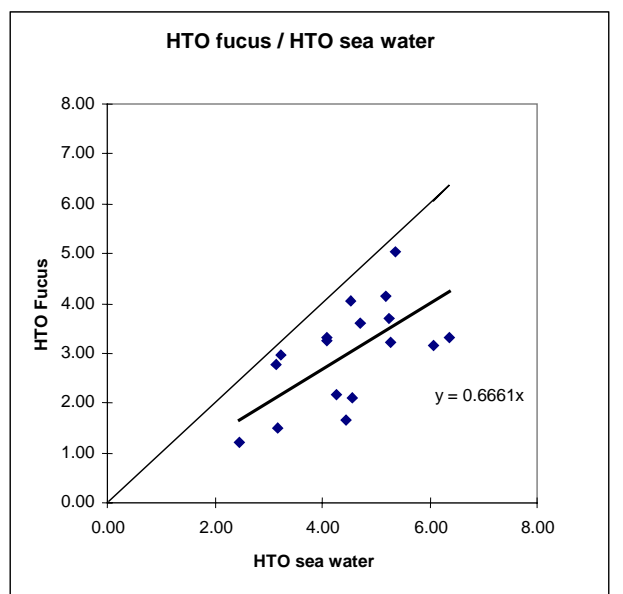

$\mathrm{a}$

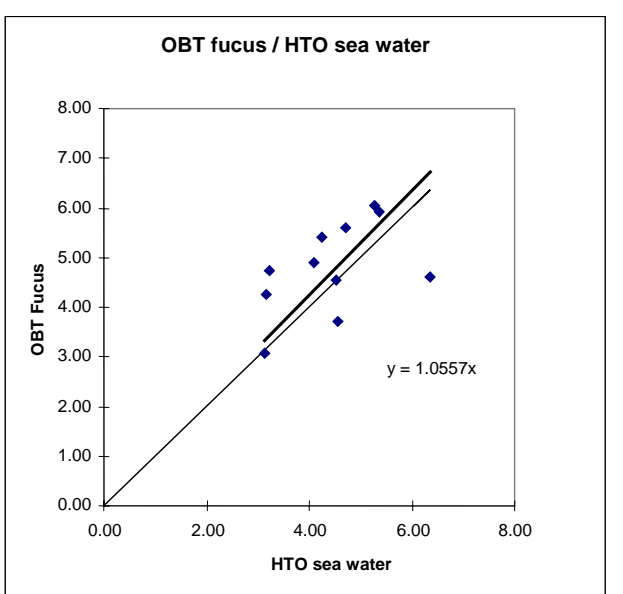

$\mathrm{b}$

Figure 6. Relationship between HTO in seawater and HTO in algae (a) and OBT in algae (b).

Table 1. Comparison of average HTO and OBT concentrations (Bq. $\mathrm{l}^{-1}$ ) in algae, molluscs and fish at Gravelines.

\begin{tabular}{|c|c|c|c|c|c|c|c|}
\hline \multirow{2}{*}{ Gravelines } & Seawater & \multicolumn{3}{|c|}{ HTO } & \multicolumn{3}{c|}{ OBT } \\
\cline { 3 - 8 } & & Algae & Molluscs & Fish & Algae & Molluscs & Fish \\
\hline Average & $\begin{array}{c}3.7 \pm 0.8 \\
(\mathrm{n}=5)\end{array}$ & $\begin{array}{c}3.2 \pm 1,2 \\
(\mathrm{n}=7)\end{array}$ & $\begin{array}{c}2.8 \pm 0.4 \\
(\mathrm{n}=3)\end{array}$ & $\begin{array}{c}3.2 \pm 0.3 \\
(\mathrm{n}=3)\end{array}$ & $\begin{array}{c}5.7 \pm 1.3 \\
(\mathrm{n}=7)\end{array}$ & $\begin{array}{c}7.1 \pm 1.2 \\
(\mathrm{n}=3)\end{array}$ & $\begin{array}{c}4.7 \pm 0.5 \\
(\mathrm{n}=3)\end{array}$ \\
\hline
\end{tabular}

Table 2. Comparison of average HTO and OBT concentrations (Bq. $\mathrm{l}^{-1}$ ) in algae, molluscs, crustaceans and fish at Concarneau.

\begin{tabular}{|c|c|c|c|c|c|c|}
\hline Concarneau & \multirow{2}{*}{ Seawater } & HTO & \multicolumn{3}{|c|}{ OBT } \\
\cline { 3 - 7 } & $\begin{array}{c}\text { Algae, molluscs, } \\
\text { crustaceans, fish }\end{array}$ & Algae & Molluscs & Crustaceans & Fish \\
\hline Average & $<1.2$ & $<1.2$ & $\begin{array}{c}1.3 \pm 0.3 \\
(\mathrm{n}=5)\end{array}$ & $\begin{array}{c}2.5 \pm 1.8 \\
(\mathrm{n}=2)\end{array}$ & $\begin{array}{c}2.6 \\
(\mathrm{n}=1)\end{array}$ & $\begin{array}{c}1.6 \pm 0.7 \\
(\mathrm{n}=3)\end{array}$ \\
\hline
\end{tabular}

\section{DISCUSSION}

From 1983 to 1985, concentrations measured in the north Atlantic surface water off the French coast were comprised between 0.4 and 0.9 Bq. $\mathrm{l}^{-1}$ [5]. At the same period, in the English Channel, in the region of the Penly site, the concentrations measured within the scope of the Penly radioecological zero point were comprised between 1.5 and 3.9 Bq. $\mathrm{l}^{-1}$. In 1994, concentrations in the Atlantic Ocean were 0.3 Bq. $\mathrm{l}^{-1}$ 
and reached 6 Bq. $\mathrm{l}^{-1}$ along the coast of the eastern English Channel [6]. It can therefore be noted over the last 20 years that the tritium concentration in waters entering the English Channel has slowly decreased, and that the tritium concentration of the English Channel waters has slowly increased. This means that on the one hand, the influence of nuclear weapon tests fallout has dwindled, and on the other hand, the production capacities of nuclear industry along the English Channel coast has increased.

Contrary to the trend in the increase noted on tritium concentrations in seawater, the results of measurements of tritium bound to organic matter on marine organisms have tended to decrease over the last 20 years (Table 3).

Table 3. Tritium bound to organic matter (Bq. $\mathrm{l}^{-1}$ of combustion water) in the marine environment in the English Channel from 1981 to 1995 (unpublished data from IRSN and EDF).

\begin{tabular}{|c|c|c|c|c|c|}
\hline Site-year & Fucus & Crustaceans & Molluscs & Fish & Sediments \\
\hline $\begin{array}{c}\text { Flamanville } \\
\text { (zero point)-1981 }\end{array}$ & 24 to 41 & 152 to 185 & 26 to 174 & 126 to 174 & \\
\hline Gravelines 1992 & 10.3 & & 20.3 & & 89 \\
\hline Paluel 1995 & 4.7 to 5.9 & 6.5 to 7.6 & 6.5 to 13.6 & & \\
\hline
\end{tabular}

This evolution might be explained by a marking of the trophic chain by more and more reduced quantities of releases of organically bound tritium of continental origin, in particular by the tributary basins of the Seine river for eastern English Channel stations, from the Loire river for the Concarneau station. This organic tritium might result from the slow breakdown of lignin and cellulose substances present in the organic matter of higher plants exposed to decreasing activities of atmospheric tests fallout or comprise unbiodegradable synthetic polymers marked with tritium. Thus, in the Loire river in 1999, bound tritium concentrations up to $100 \mathrm{~Bq} \cdot \mathrm{l}^{-1}$ of combustion water were measured in the sediments sampled at Belleville [7].

The lack of balance between the different chemical forms of tritium may explain that the concentration factor of tritium between free water and water bound to aquatic organisms is greater than one, the value, which is generally adopted in models [8]. Considerably greater tritium concentration factors, up to $10^{4}$, were determined between seawater and marine species, in particular fish, in the Severn estuary (UK) [9]. They should be compared to the tritium organic forms present in the authorized releases from the plant manufacturing marked molecules, Amersham plc, at Cardiff [10].

Other hypotheses may also be expressed to explain the OBT/HTO ratios greater than 1 in the organisms sampled within the scope of this study:

- an exchange with the atmospheric HTO when organisms are emerged. The OBT/HTO ratios, which are greater for molluscs and algae than for fish remaining always immerged, are consistent with this hypothesis (respectively 2.49, 1.97, 1.45 at Gravelines);

- an isotopic discrimination during freeze-drying. The free tritium concentrations, which are lower in living organisms than in seawater, might be an argument for it. This mechanism has already been addressed by other authors [11].

\section{Acknowledgments}

The authors deliver thanks to B.Fiévet (IRSN-LRC) for the data concerning the Goury plant and to Mrs. Henry (COGEMA La Hague) for the data concerning the Herquemoulin plant. They also deliver thanks to P.Maurin (CNRS-Roscoff) for the seawater samples during the OVIDE mission in the Atlantic Ocean. 


\section{References}

[1] Maro D., Germain P., Calmet D. and Fournier M. Rapport IPSN/SERE/98-029 (P), (1998).

[2] Bailly du Bois P. Rapport IRSN/ DPRE/SERNAT/2003-04 (2003).

[3] Fournier M., Coreau N. and Maigret A in: Proceeding of the international congress ECORAD 2001. Radioprotection - Colloques 37, C1 (2002) 973-978.

[4] Germain P., Masson M. and Baron Y. Rapport CEA / R / 5534 (1990).

[5] Nies H. In Radionuclides: a tool for oceanography. (Elsevier Science Publishers). (1988). 250-259.

[6] Bailly du Bois P. and Guéguéniat P., Cont.Shelf Res. 19 (1999) 1977-2002.

[7] Leprieur F. and Gontier G. Rapport DPRE /SERNAT /2000-12. (2000) 159P.

[8] IAEA. IAEA Technical Report Series (Vienna : IAEA) 247 (1985) 71 pp.

[9] Williams J., Russ R.M., Mc Cubbin D. and Knowles J.F. J.Radiological Protection 21 (2001), 337-344.

[10] Swift D.J. and Hughes L.M. Tritium and carbon-14 in the marine environment. Environment Report RL05/03 (2003) 47 pp.

[11] Belot Y., Roy M. and Métivier H. Le tritium de l'environnement à l'homme. Les éditions de physiques (1996) $191 \mathrm{pp}$. 